\title{
An Empirical Examination of the Socio-Economic Consequences of Corona Virus Disease 2019 (Covid-19) Outbreak in US, UK, Germany and China: A Structural Equation Modelling Approach
}

\author{
Titilope Akinsanmi \\ Department of Public Policy \& Urban Affairs, Southern University and A \& M College, Baton Rouge, \\ Louisiana, USA
}

\begin{abstract}
This paper critically examines the socio-economic impact of the Corona virus Disease 2019 (COVID-19), focusing on four developed nations of the world, including China, Germany, UK and US. Survey data was used to analyze the relationship between eight critical socio-economic variables, including economic stability, daily living, mental health, worry about COVID-19, satisfaction with the national government's response to the COVID-19, people's personal finances, satisfaction with fellow citizens' response to the COVID-19, and satisfaction with hospitals' response to the COVID-19. Considering the complexity of the interrelationship between the variables, a structural equation modelling approach was used to assess the impact of the COVID-19 on these variables. Result shows that the COVID-19 pandemic has affected the daily lives of people. This is also having negative effect on their ability to contribute meaningfully to economic activities, which ultimately affects the economic stability of their nations as a whole. The result from this study also shows the importance of the health sector in nation-building. The health sector has critical roles to play beyond taking care of the sick that have contracted the COVID-19. The health sector is critical in inspiring confidence in the public and causing citizens to be mentally, psychologically and emotionally stable. Mental stability is needed for citizens to carry out their economic activities and contribute meaningfully to economic stability; therefore, the health sector has important role to play during and after the COVID-19 outbreak. The findings from this paper draws the attention of the government as a critical force in resuscitating the economy post COVID-19. The government would have to formulate and implement policies that will inspire confidence as at present, people are somewhat not satisfied with the national government's response to the COVID-19 / coronavirus pandemic, as the level of satisfaction is just average.
\end{abstract}

Keywords: corona virus; COVID-19; disease; pandemic, economic stability; socio-economic; wellbeing, structural-equation.

DOI: $10.7176 / \mathrm{IAGS} / 68-04$

Publication date:July $31^{\text {st }} 2020$

\section{INTRODUCTION}

There is no denying that the world was taken by surprise at the outbreak of the Corona virus Disease 2019 (COVID19). 'The novel coronavirus, commonly referred to as the global pandemic COVID-19 has without warning disrupted democracies, shocked economies and forever changed life as many humans globally know it' (Oseni, 2020). The disease originated from Wuhan, in China and rapidly spread all over the world (World Health Organization, 2020). Virtually all countries of the world were hit and adversely affected by the COVID-19 outbreak (The New York Times (2020; World Health Organization, 2020). The disease outbreak has paralyzed socio-economic activities, as people have been restricted in their daily activities in a bid to stay safe and control the further spread of the virus (Centers of Disease Control and Prevention, 2020).

As shown in Figure 1, the COVID-19 virus is ubiquitous and has killed a considerable number of people all over the world. The death toll as at April 23,2020 was 184,249. The ubiquity and fast spread of the virus has affected and is still affecting human activities. People, organizations, societies and nations have suffered one form of loss or the other, including economic loss. The COVID-19 outbreak is seriously and quickly shaping the manner of operations of both private and public sector organizations. 
Table 1: Number of Novel Coronavirus (COVID-19) deaths worldwide as of April 23, 2020, by country (focus on countries reporting a minimum of 500 deaths)

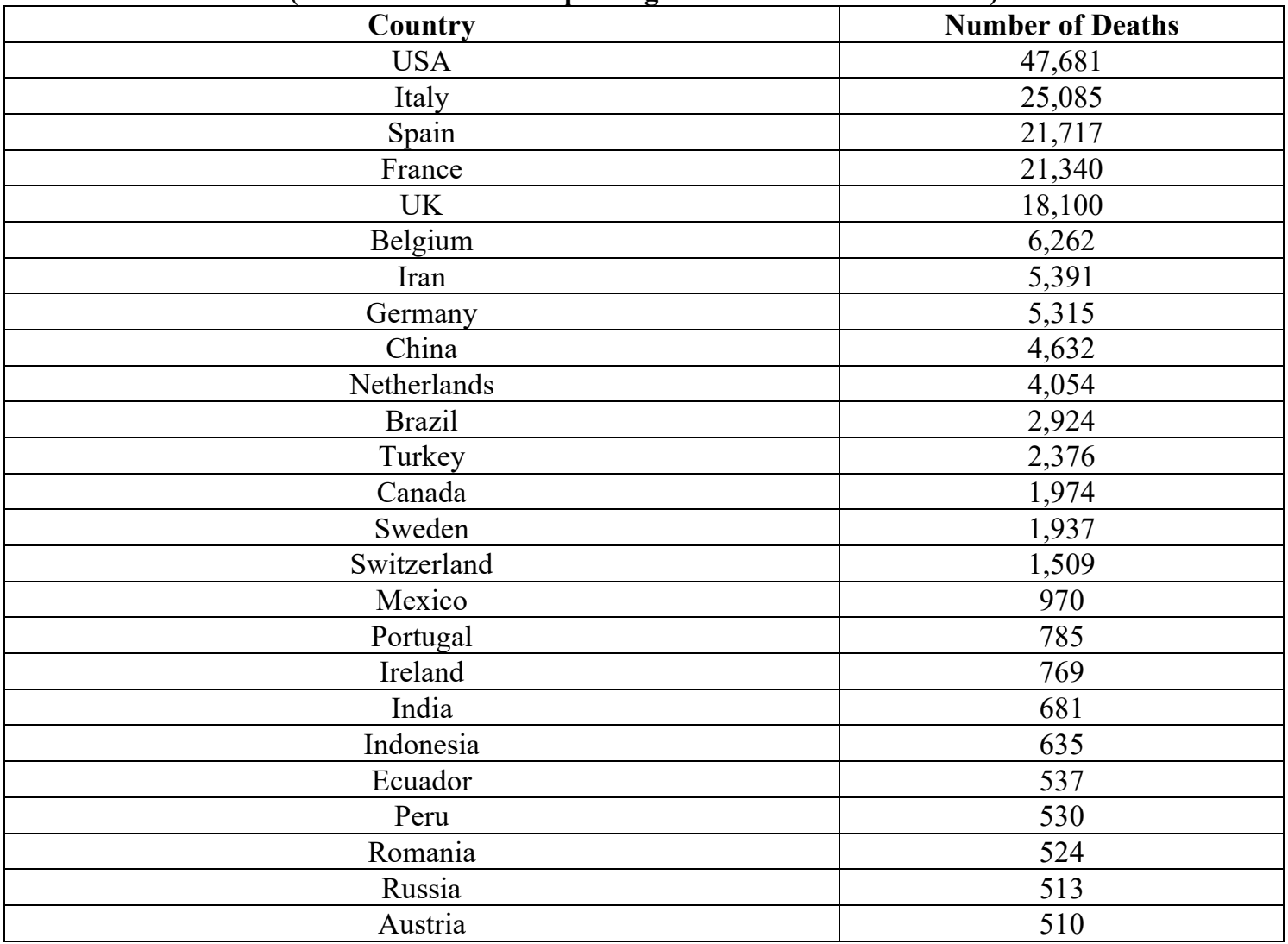

Source: Curled from statistica (https://statistica.com).

Whilst it is acknowledged that the COVID-19 outbreak has affected all spheres of human endeavors, including socio-economic dimensions (Clamp, 2020; Nikel, 2020), it becomes necessary to investigate the extent to which the emotional, psychological, mental, social, financial and economic wellbeing of people and nations have been affected. Conventional theory of human resource management such as the motivation theories have suggested that safety need is paramount and prime amongst the needs of human. The hierarchy of need theory was propounded by Abraham Maslow to model how human needs can be used to motivate an individual/ the work force. The Abraham Maslow theory falls under the human approach to management (Mullins \& Christy, 2013). The human approach to management emphasizes the need for organizations to show concern for the needs to employee, as against the excessive focus on work alone (as advanced in the scientific and bureaucratic approach to management). Maslow posited that an organization should seek to address the needs of employees as a means of motivating them, because a highly motivated individual is expected to put in his/her best and contribute optimally to the achievement of organizational goals (BPP, 2008; Boddy, 2012). Thus, organizations can set reward around the human needs to cause employees to strive for superior performance. To this end, Maslow identified five cogent needs of a human being, in the ascending order of physiological needs, safety needs, belonging needs, self-esteem needs, and self-actualization (Mullins \& Christy, 2013). These needs are usually delineated using a pyramid, with the lowest need (i.e. physiological needs) at the bottom of the pyramid and the highest-ranking need (self-actualization) at the top of the pyramid.

Physiological needs are the basic needs fundamental to the livelihood of any humans such as food, clothing, shelter, sex, among others. Organizations address physiological needs by providing or monetizing benefits through high remuneration that cover these needs. After the physiological need is the safety need. This refers to security of live and properties of individuals. Organizations address the safety needs of employees by providing safe working environmental for employees to ensure they are physiologically stable to contribute optimally to the organization (Boddy, 2012). Safety needs are also reinforced by guaranteeing employees job security as a form of social contract. In a social contract, it is expected that an employee performs optimally on the job, while management in return meet the needs of employees through good working condition and competitive remuneration (Aboramadan \& Borgonovi, 2016).

Next is the social needs/ security need. It refers to the longing of an individual to associate with other people as a social being. Whereas the physiological and safety needs appeal to individuals as psychological beings, the social need recognizes employees as social beings. Organizations reinforce social needs of employees by ensuring 
they work in groups, units or departments where they are considered relevant, and where they can function effectively based on their capabilities (AbuKasim \& Minai, 2009).

After the social need is the self-esteem need. This refers to the dignity of a human being as a psychological and social being. It refers to the need for self-respect and the respect of other individuals. Organizations reinforce social needs by ensuring policies are in place to edify dignity of human labor. Organizations will also ensure that work practices are ethical; and that labor do not work for excessively long duration, and will also ensure that remuneration commensurate with efforts, time and intellectual input of employees. Self-actualization is the highest stage of the human need hierarchy. It refers to the point when a human being feels a sense of accomplishment, fulfilment and satisfaction with the level of achievement and success. Self-actualization also refers to the innate desire in every human to reach the top of his/her career and achieve high performance. Maslow argues that once a need on the hierarchy is met, an individual move to the next hierarchy of need, until s/he gets to the stage of actualization. Maslow pointed that an individual can move in quick succession from one hierarchy of need to another (Abramovitz, 2017).

The contextualization of the Abraham Maslow's theory to the current study on factors influencing peoples' behavior following the outbreak of the COVID-19 pandemic implies that people will take precautionary measures and government will institute safety measures to preserve human lives as these are physiological and safety needs ranking high and are foremost among the hierarchy of needs (Garrett, 2008). The need for survival will cause organizations to ensure social distancing measures such as working from home so that people do not work to the detriment of their health (psychological needs) and personal safety (safety needs). When an organization regards their employees as important human beings, and if such organization has respect for the dignity of human labor (self-esteem need), it will not find it hard to recognize that employees should have a life beyond the four walls of their workplace, and can work remotely at a time of global pandemic when COVID-19 is ravaging lives (Gray, 2009). Organizations that are socially responsible and are guided by social sustainability practice will respect the lives of individuals by instituting work practices that ensure a balance between work life and personal life (selfesteem need) during a period of global health crisis such as the on-going COVID-19 outbreak. It is when the safety of a person is secured or guaranteed that $\mathrm{s} / \mathrm{he}$ will aspire to satisfy other needs in the hierarchy of human philosophy such as social/ belonging, self-esteem, and self-actualization needs (Hye, 2014). Prior studies on employees' productivity have invoked the motivation theory to explain human behavior and disposition to work during a period of crisis (e.g. Jensirani \& Muthuman, 2017; Avgar, Givan \& Liu, 2011)

With no whiff of doubt, the COVID-19 has threatened and is still threatening the safety of human lives, as everyone makes effort to first survive before seeking to carry on daily activities and contribute meaningfully to the society (Government of the United Kingdom, 2020; Phillison, 2000). However, little is known as to the socioeconomic consequences of the COVID-19 based on empirical analysis. In the light of these developments, this study investigates the socio-economic impact of the COVID-19 outbreak, with a focus on four countries- United States, United Kingdom, Germany and China. The focus on the four countries is justified on the basis that they are part of the developed countries that are worst hit by the COVID-19 outbreak as shown in Table 1. USA has the highest number of deaths $(47,681$ as at April 23, 2020); UK has a death toll of 18,100; Germany and China have death tolls of 5,315 and 4,632 respectively (Table 1). It, then, becomes important to unearth the socio-economic impact of COVID-19 in these countries.

Survey Data on eight critical socio-economic variables, including economic stability, daily living, mental health, worry about COVID-19, Satisfaction with the national government's response to the COVID-19, people's personal finances, Satisfaction with fellow citizens' response to the COVID-19, and Satisfaction with hospitals' response to the COVID-19 covering the four countries under consideration was obtained and empirically analyzed using structural equation modelling considering the complexity of the interrelationship between these socioeconomic variables investigated. Result shows that the COVID-19 pandemic has affected the daily lives of people. This is also having negative effect on their ability to contribute meaningfully to economic activities, which ultimately affects the economic stability of their nations as a whole. The findings from this paper draws the attention of the government as a critical force in resuscitating the economy post COVID-19. The government would have to formulate and implement policies that will inspire confidence as at present, people are somewhat not satisfied with the national government's response to the COVID-19 / coronavirus pandemic, as the level of satisfaction is just average.

The result from this study also shows the importance of the heath sector in nation-building. The health sector has critical roles to play beyond taking care of the sick that have contracted the COVID-19. The health sector is critical in inspiring confidence in the public and causing citizens to be mentally, psychologically and emotionally stable. Mental stability is needed for citizens to carry out their economic activities and contribute meaningfully to economic stability; therefore, the health sector has important role to play during and after the COVID-19 outbreak.

This study contributes to knowledge in that it is the first, to the author's knowledge, to analyze the socioeconomic impact of the COVID-19 outbreak using a structural equation modelling approach. The originality of the paper also stems from the consideration that it integrates data from four major developed countries of the world, 
thereby extending the generalizability of the result.

The rest of the paper proceeds as follows. The methodology adopted for the study is explained in section 2 . This is followed by presentation of results from descriptive analysis in section 3. Next, the results from structural equation modeling is presented in section 4 . The paper is concluded in section 5.

\section{METHODOLOGY}

Quantitative research design was adopted for the study using the survey method. Survey research design was selected because it affords the researcher the opportunity to gather quantitative data conveniently and economically from large number of respondents (Ghauri \& Grønhaug, 2005). However secondary survey data was used covering the four countries under focus. The variables of the study and how they were measured is presented in Table 2.

Table 2: Measurement of Variables

\begin{tabular}{|l|l|l|}
\hline S/N & $\begin{array}{l}\text { Variable } \\
\text { Name }\end{array}$ & Measurement and Connotation \\
\hline 1 & Economy & $\begin{array}{l}\text { economic stability as a result of the COVID-19 / coronavirus pandemic in the United States, } \\
\text { United Kingdom, Germany and China 2020 }\end{array}$ \\
\hline 2 & Life & $\begin{array}{l}\text { Level of impact of the COVID-19 / coronavirus pandemic on people's everyday life in the } \\
\text { United States, United Kingdom, Germany and China 2020: } \\
\text { SCALE 1 (No impact at all) to 10 (severely impacted) }\end{array}$ \\
\hline 3 & Mental & $\begin{array}{l}\text { Share of persons worried about their mental health because of the COVID-19 / coronavirus } \\
\text { pandemic in the United States, United Kingdom, Germany and China 2020 }\end{array}$ \\
\hline 4 & Worry & $\begin{array}{l}\text { Share of persons most worried about the COVID-19 / coronavirus pandemic in the United } \\
\text { States, United Kingdom, Germany and China }\end{array}$ \\
\hline 5 & Govt. & $\begin{array}{l}\text { Satisfaction with the national government's response to the COVID-19 / coronavirus } \\
\text { pandemic in the United States, United Kingdom and Germany 2020 }\end{array}$ \\
\hline 6 & Finance & $\begin{array}{l}\text { Level of impact of the COVID-19 / coronavirus pandemic on people's personal finances in } \\
\text { the United States, United Kingdom, Germany and China 2020. } \\
\text { SCALE 1 (No impact at all) to10 (severely impacted) }\end{array}$ \\
\hline 7 & Citizen & $\begin{array}{l}\text { Satisfaction with fellow citizens' response to the COVID-19 / coronavirus pandemic in the } \\
\text { United States, United Kingdom, Germany and China 2020 }\end{array}$ \\
\hline 8 & Hospital & $\begin{array}{l}\text { Satisfaction with hospitals' response to the COVID-19 / coronavirus pandemic in the United } \\
\text { States, United Kingdom and Germany 2020 }\end{array}$ \\
\hline
\end{tabular}

Source: Author's Modification

\subsection{Method of Data Collection}

Survey Data on the COVID 19 pandemic covering the four countries under consideration were obtained from the database of statistica (https://statistica.com). The data covered the eight variables enumerated in Table 1 for the four countries for 30-daily observations, making a total of 960 observations used in the analysis. The survey spanned across two months (March to April 2020) when the COVID-19 cases peaked all over the world. The use of survey data covering this period is adjudged appropriate considering that this was the peak period when the government of nations started restricting movement, imposing curfews and invoking lockdown as measures to contain the spread of the virus. Thus, survey data generated this period is considered to be a reflection of the severity of the COVID-19 outbreak on social and economic system. The focus on the four countries is justified on the basis that they are part of the countries worst hit by the COVID-19 outbreak (Table 1 shows the death toll per country affected by the COVID-19 outbreak). Considering the complexity of the interrelationship between the variables, a structural equation modelling approach was used to assess the impact of the COVID-19 on these variables. Data analysis was aided by STATA 14 software. 


\section{DATA ANALYSIS, RESULTS AND PRESENTATION}

Descriptive statistics of the variables is presented in Table 3

Table 3: Descriptive Statistics

\begin{tabular}{|l|r|r|r|r|r|}
\hline \multicolumn{1}{|c|}{ Variables } & N & Minimum & Maximum & \multicolumn{1}{c|}{ Mean } & \multicolumn{1}{c|}{ Std. Deviation } \\
\hline Economy & 120 & 41.00 & 80.00 & 61.3083 & 7.66504 \\
Life & 120 & 6.00 & 7.70 & 6.9208 & .38236 \\
Mental & 120 & 8.00 & 43.00 & 26.9250 & 6.64485 \\
Worry & 120 & 37.00 & 70.00 & 56.5667 & 7.37328 \\
Govt & 120 & 25.00 & 66.00 & 51.0333 & 10.43056 \\
Finance & 120 & 3.60 & 6.70 & 5.2658 & .78884 \\
Citizen & 120 & 12.00 & 86.00 & 47.3250 & 17.77977 \\
Hospital & 120 & 64.00 & 91.00 & 79.6333 & 5.94818 \\
Valid N (listwise) & 120 & & & & \\
\hline
\end{tabular}

\section{Source: Author's Analysis}

From the result in Table 3, a sizable number of respondents are worried about the economic stability of their country as a result of the COVID-19 outbreak because the Mean score of 61.3083, meaning that on the average, $61.3 \%$ of the persons survey are worried about the impact of COVID-19. With a mean of 6.9208 on a 10-point scale for life, most respondent agree that their everyday live is severely impacted by the COVID-19/ coronavirus pandemic. It appears that a smaller number of people $(26.9250 \%)$ are worried about their mental health because of the COVID-19. However, a greater proportion (56.5667\%) are most worried about the COVID-19 / coronavirus pandemic. People are somewhat not satisfied with the national government's response to the COVID-19/ coronavirus pandemic, as the level of satisfaction is just average $51.0333 \%$. With a Mean of 5.2658 on a 10 -point scale for Finance, it appears the severity of the impact of the COVID-19 / coronavirus pandemic on people's personal finances is generally moderate. People appear not to be satisfied with fellow citizens' response to the COVID-19 / coronavirus pandemic, as the Mean score for Citizen is $47.3250 \%$ which is below average. With a mean of $79.6333 \%$ for Hospital, people seem to be generally well satisfied with hospitals' response to the COVID19 / coronavirus pandemic. These statistics suggests that people are concerned about the socio-economic impact of the COVID-19 outbreak, which provides a good basis to critically examine the psychological, social and economic impact of the global health crisis caused by the COVID-19 outbreak.

\section{Results from Structural Equation Analysis}

Results from structural equation analysis is presented in Tables 4 to 7, Figure 1 (without standardized estimates) and Figure 2 (displaying the standardized estimates of regressors).

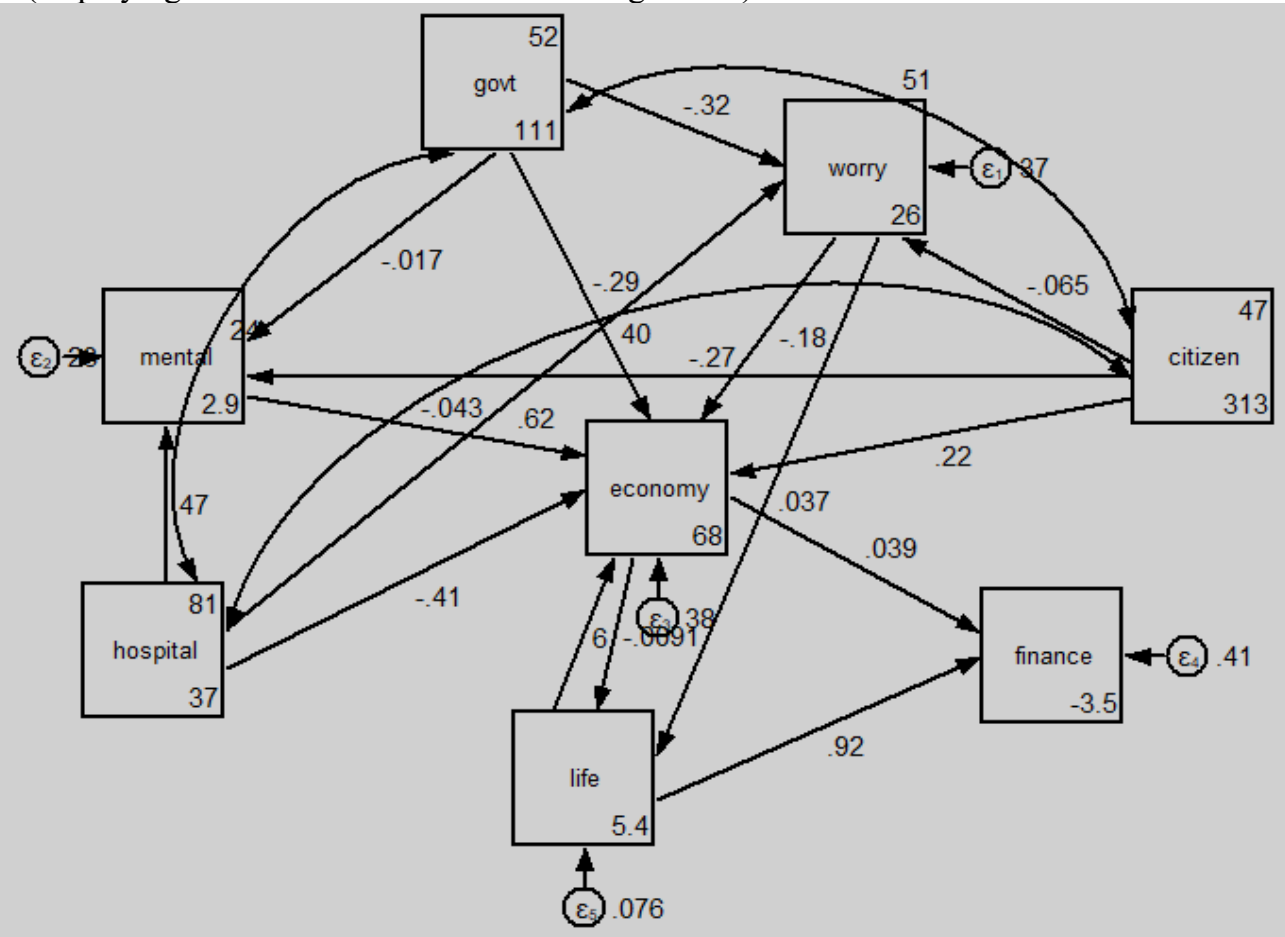

Figure 1: SEM Model on the Socio-Economic Impact of COVID-19 [without standardized estimates] 


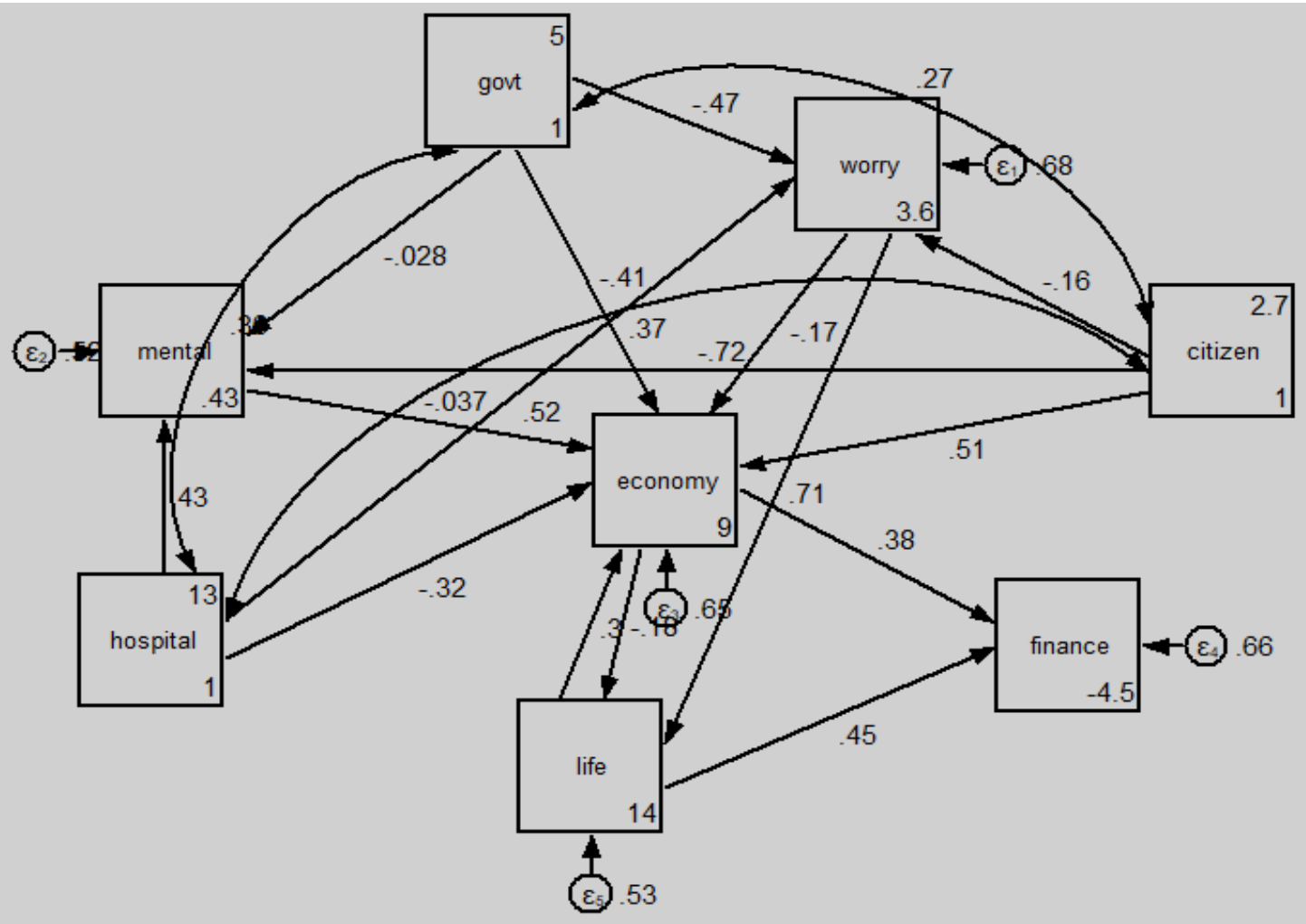

Figure 2: SEM Model on the Socio-Economic Impact of COVID-19 [showing standardized estimates of

Source: Author's Analysis regressors]

Presentation of Path Analysis: Direct Effect

Result on the direct effect among variables is presented in Table 4.

Table 4: Direct Effect Analysis of the Socio-Economic Impact of COVID-19

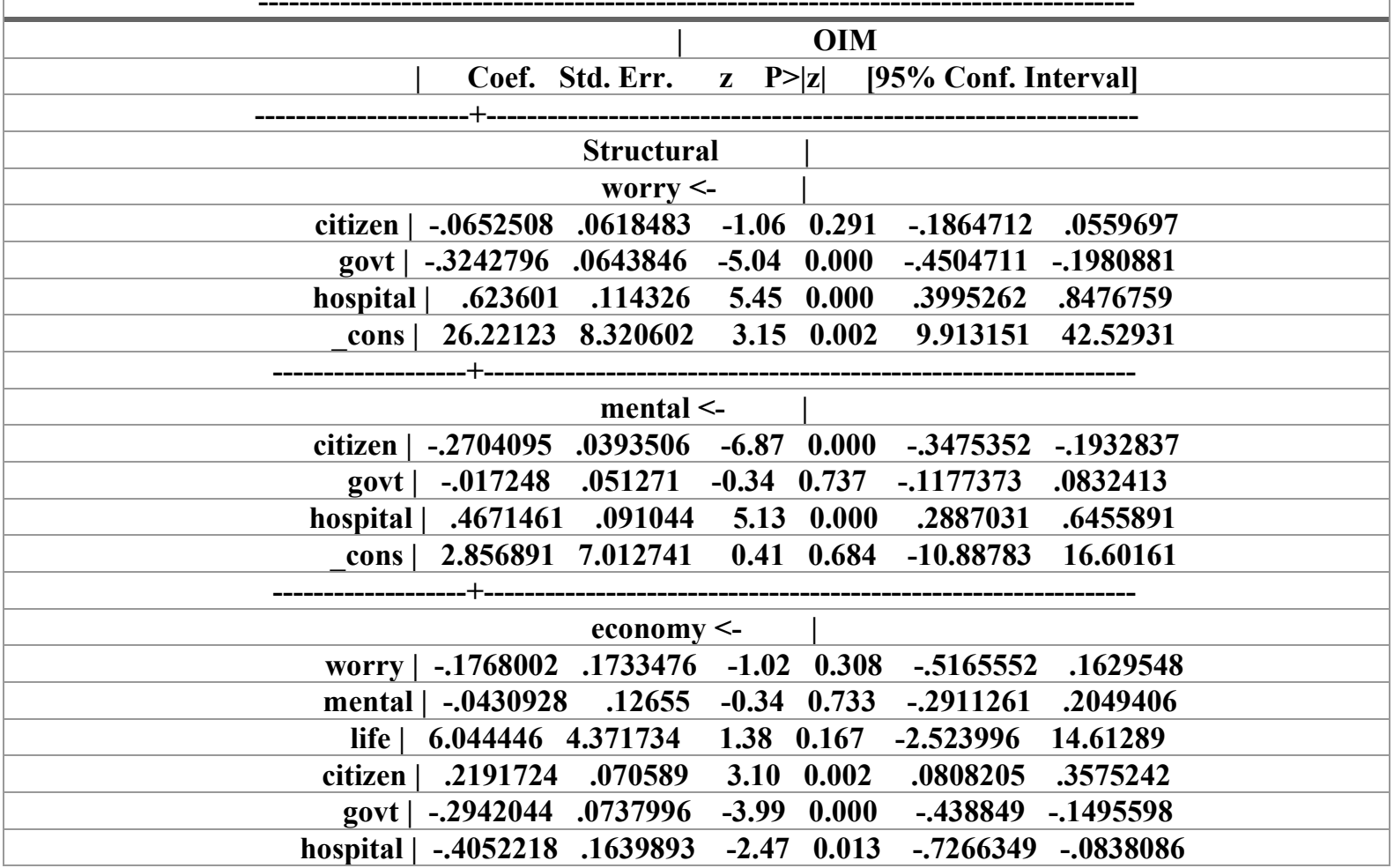




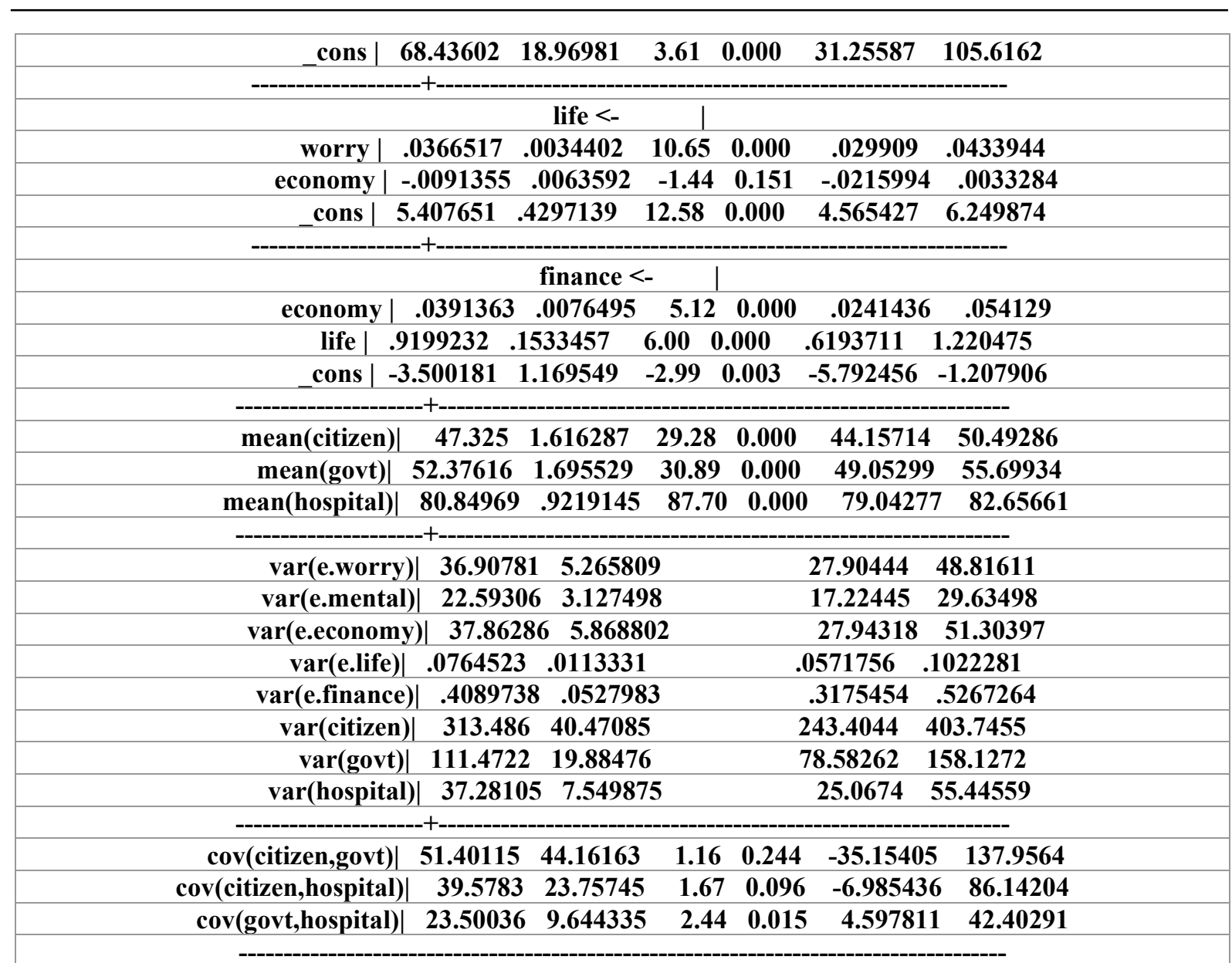

Source of data: Author's Analysis

\subsection{DISCUSSION OF PATH ANALYSIS AND ITS ASSOCIATED DIRECT EFFECT ANALYSIS OF THE SOCIO-ECONOMIC IMPACT OF COVID-19}

\subsubsection{Factors Affecting Psychological stability (i.e. worry about COVID 19)}

Result shows that govt and hospital significantly affect psychological stability while citizen exert no such influence. The emergence of govt as a significant predictor demonstrates the role of government in ensuring psychological well-being. Government is tasked with improving the livelihood of people, and one of the dimensions of governance quality is protection of lives and properties. When government contributes to psychological stability by taking steps to contain the spread of COVID, they inspire the confidence of the citizens and allay their worries about COVID-19. This result reiterates the great responsibilities that government has in building the society and seeing to the psychological wellbeing of citizens.

The emergence of hospital as a significant predictor of Psychological stability demonstrates the criticalness of the healthcare sector and the contributions of health practitioners in engendering economic stability. The health sector inspires confidence by staying on top of the COVID pandemic.

\subsubsection{Factors Affecting Mental Stability}

Citizen and hospital affect have significant coefficients, meaning that they notably affect mental stability. The actions of other citizens such as taking precautionary measures, and the robust response of the healthcare providers contribute significantly to mental stability.

Overall, hospital has a significant coefficient on both psychological and mental stability. This buttresses the criticality of the health sector to stemming the tide of the COVID-19 outbreak. Thus, reinvigorating the health sector is crucial to recovering from the socio-economic impact of the COVID-19 pandemic.

4.1.3 Factors Affecting Economic stability

The factors affecting economic stability are Satisfaction with fellow citizens' response to the COVID-19 / coronavirus pandemic (citizen), Satisfaction with the national government's response to the COVID-19/ coronavirus pandemic (govt), and Satisfaction with hospitals' response to the COVID-19 / coronavirus pandemic (hospital). However, factors such as being worried about the COVID-19 / coronavirus pandemic (worry), being worried about their mental health because of the COVID-19 / coronavirus pandemic (mental) and impact of the COVID-19 / coronavirus pandemic on people's everyday life (life) exert no significant impact. 
The emergence of citizen as a significant predictor of economic stability implies that everyone has a responsibility to sustain the economy by taking precautionary measures to contain the spread of COVID-19. This may be expected considering that the everyday activity of people contributes to nation building, and if the health of citizens cannot be guaranteed, this will affect their ability to contribute meaningfully to nation building and this may have serious impact on the economy.

The emergence of govt as a significant predictor of economic stability also corroborates the criticalness of government in inspiring confidence in the citizenry through steps taken to control the spread of COVID-19. The result also buttresses argument in literature that government has a responsibility of protecting lives and properties of citizens, including the livelihood of people. Furthermore, the result demonstrates the role of government in formulating policies that ensure socio-economic stability.

The emergence of hospital as a significant contributor to economic stability connotes that the health sector is critical to nation-building, because the ability of hospitals to inspire confidence in the citizens may give them the impetus to face the day in spite of the health uncertainty and contribute significantly to the economy. This result also provides support for argument that a healthy nation makes a wealth nation. As a result, government would have to formulate and implement policies that strengthens the health sector.

Although the coefficient of worry is not statistically significant, the beta coefficient is negative $(b=$ -.1768002). This implies that worrying about the COVID 19 negatively affect the economy. This trend may be explained by the fact that when people are not psychologically balanced due to fear, it affects their productivity negatively and the entire economy adversely. This result also corroborates the earlier argument that the health sector is critical in ensuring economic stability. Hospitals can allay the fear and worry of the citizens by inspiring confidence in them. When such worries are addressed, it may be expected that citizens can be psychologically balanced to contribute to economic stability.

Result also shows that although mental has no statistically significant coefficient, its impact on economic stability is negative $(b=-.0430928)$. This implies that when people are worried about their mental health, they will not be psychologically fit as to contribute meaningfully to economic development. Stated in other words, it is only when people are psychologically balanced that they will be able to pursue their economic activities with vigor. Thus, mental imbalance negatively affects economic stability. Again, this result corroborates the role of the health sector in engendering economic stability by inspiring confidence in citizens as to ensure they are mentally balanced to contribute to economic advancement of their nations.

Result also shows that life has a positive but statistically insignificant coefficient $(b=6.044446)$ on economic stability. This means that the daily activities of people affect economic stability. This result also buttresses the earlier result that the mental state of people affects the economy because the daily activities of people is a function of their mental health.

Overall, the analysis of the factors affecting economic stability shows that the mental or psychological state of people affect their ability to contribute meaningfully and positively to economic stability, and the daily activities of people (which depends on their mental health) impact on economic stability.

\subsubsection{Factors Affecting Daily Living}

Worry significantly affect daily living, implying that the psychological or mental state of citizens affect their ability to perform optimally and contribute to economic development. The economy exerts no significant influence on daily life, implying that the desire for survival is paramount amongst other considerations affecting daily living.

\subsubsection{Factors Affecting people's personal finances}

Results shows that economic stability (economy) and daily living (life) significantly affect people's personal finances. This result demonstrates that economic stability greatly affects the financial prosperity of citizens. It may be expected therefore that disruption in economic activities caused by the COVID-19 outbreak will significantly and negatively impact the finance of people. The emergence of daily living as a significant determinant of personal finance corroborates the argument that the ability of people to carry on economic activities on a daily basis contributes to the economy and ultimately impact their personal finances.

\subsubsection{Citizens and Hospitals as covariates of Economic Stability}

Result shows a strong relationship between Citizens and Hospitals as covariates $(b=39.5783, p<.10)$. This implies that the steps taking by citizens to contain the spread of COVID-19 and the efforts made by hospitals in safeguarding their nation's health has far-reaching consequences on economic stability. This result also buttresses argument that containing the spread of COVID-19 and resuscitating the economy of a nation is not the sole responsibility of the government. The citizens and other sectors of the economy, including the health sector, have their roles to play in nation-building and economic recovery post-COVID 19.

\subsubsection{Government and Hospitals as covariates of Economic Stability}

Result shows a strong relationship between Government and Hospitals as covariates $(b=23.50036, p<.05)$. This implies that the steps taking by the government to contain the spread of COVID-19, the government polices to restart the economy subsequent to COVID-19 and the efforts made by hospitals in safeguarding their nation's health concurrently have has far-reaching consequences on economic stability. The result also buttresses the role 
of government in inspiring confidence and causing economic recovery post COVID-19.

\subsection{DISCUSSION OF PATH ANALYSIS AND ITS ASSOCIATED INDIRECT EFFECT ANALYSIS OF THE SOCIO-ECONOMIC IMPACT OF COVID-19}

Result on indirect effect among variables is presented in Table 5.

Table 5: Indirect Effect Analysis of the Socio-Economic Impact of COVID-19

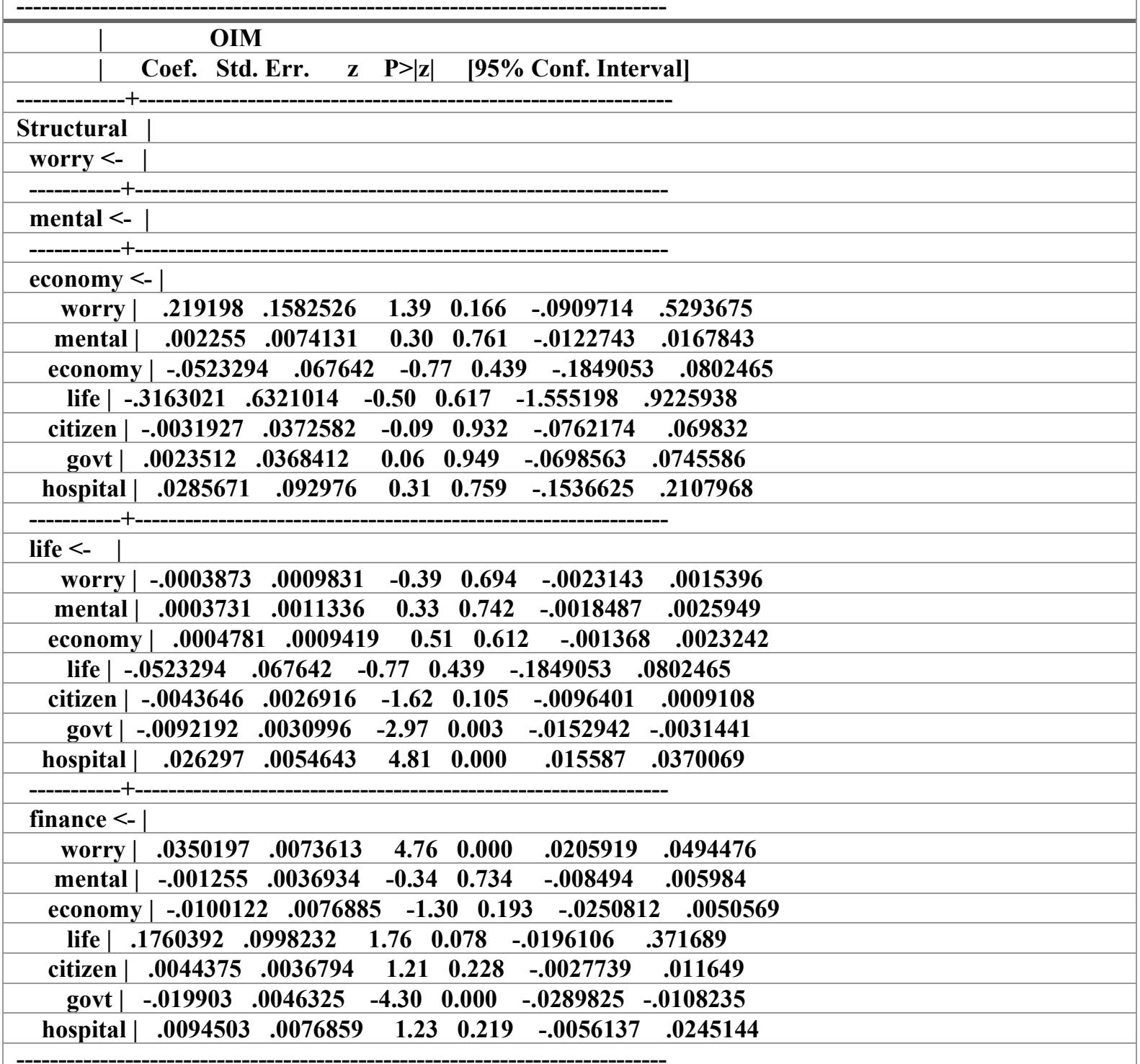

\section{Source: Author's Analysis}

In the additional analysis on the variables indirectly affecting economic stability, worry, mental, economy, life, citizen, govt and hospital all have indirect effect on economic stability. This implies that economic stability is a reflection of socio-economic wellbeing of the citizens. When people are not psychologically or mentally balanced to contribute to economic activities, it affects the entire economic progress of the nation. As the COVID19 outbreak is expected to negatively affect psychological and social wellbeing of citizens, it is expected to have negative consequences on the economy. The result also suggests that the health sector and government actions/policies affect economic prosperity.

Result also shows that worry, mental, economy, life, citizen, govt and hospital have indirectly impact on everyday lives of people (life). Amongst all these items, govt and hospital have statistically significant coefficients, implying that the actions of government and the activities of the healthcare practitioners seriously affect the daily livelihood of people.

The factors indirectly affecting the personal finance of people are worry, mental, economy, life, citizen, govt. and hospital. Worry, life and govt exert statistically significant influence on personal finance. This implies that the physiological state of people's mind will affect their personal finance; daily livelihood affects the personal finance 
of people, and government action also affects the livelihood of people. Overall, the emotional state of people affects their daily lives and their ability to carry on economic activities. Considering that the COVID-19 has affected the mental state of people, it may be expected that this will have far reaching implications for the economy. To recapitulate, govt consistently evince statistical significance for both life and finance, implying that government actions, activities and policies prominently affect the daily lives and personal finance of people. This result brings to fore the need for government to formulate the right policies to alleviate the social an economic impact of the COVID-19 pandemic.

\subsection{DISCUSSION OF PATH ANALYSIS AND ITS ASSOCIATED TOTAL EFFECT ANALYSIS OF THE SOCIO-ECONOMIC IMPACT OF COVID-19}

The combined effect (addition of the Direct and Indirect effect) of the factors affecting the socio-economic wellbeing of people and the nation as a result of the COVID-19 outbreak is presented in Table 6.

Table 6: Total Effect Analysis of the Socio-Economic Impact of COVID-19

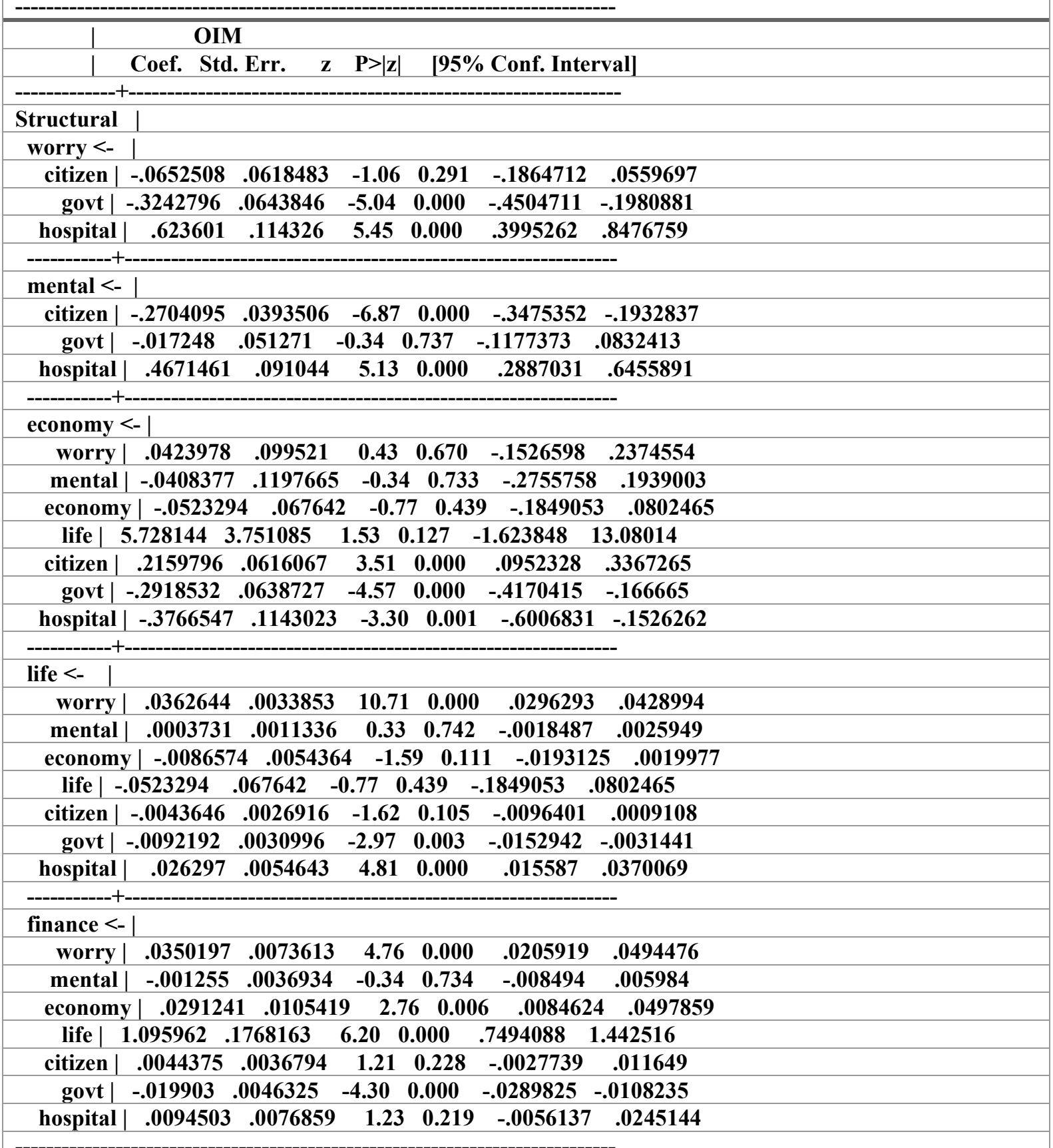


significantly affect psychological stability (i.e. worry about COVID-19). Citizen and hospital significantly affect have significant affect mental stability of people. Satisfaction with fellow citizens' response to the COVID-19/ coronavirus pandemic (citizen), Satisfaction with the national government's response to the COVID-19 / coronavirus pandemic (govt), and Satisfaction with hospitals' response to the COVID-19 / coronavirus pandemic (hospital) affect economic stability. Worry, govt and hospital significantly affect the daily lives of people. Worry, economy, life, and govt significantly affect the personal finance of people.

\subsection{MODEL FIT AND ROBUSTNESS OF RESULT}

Summary statistics on model fitness and the robustness of result is presented in Table 7.

Table 7: Model Fit Statistics

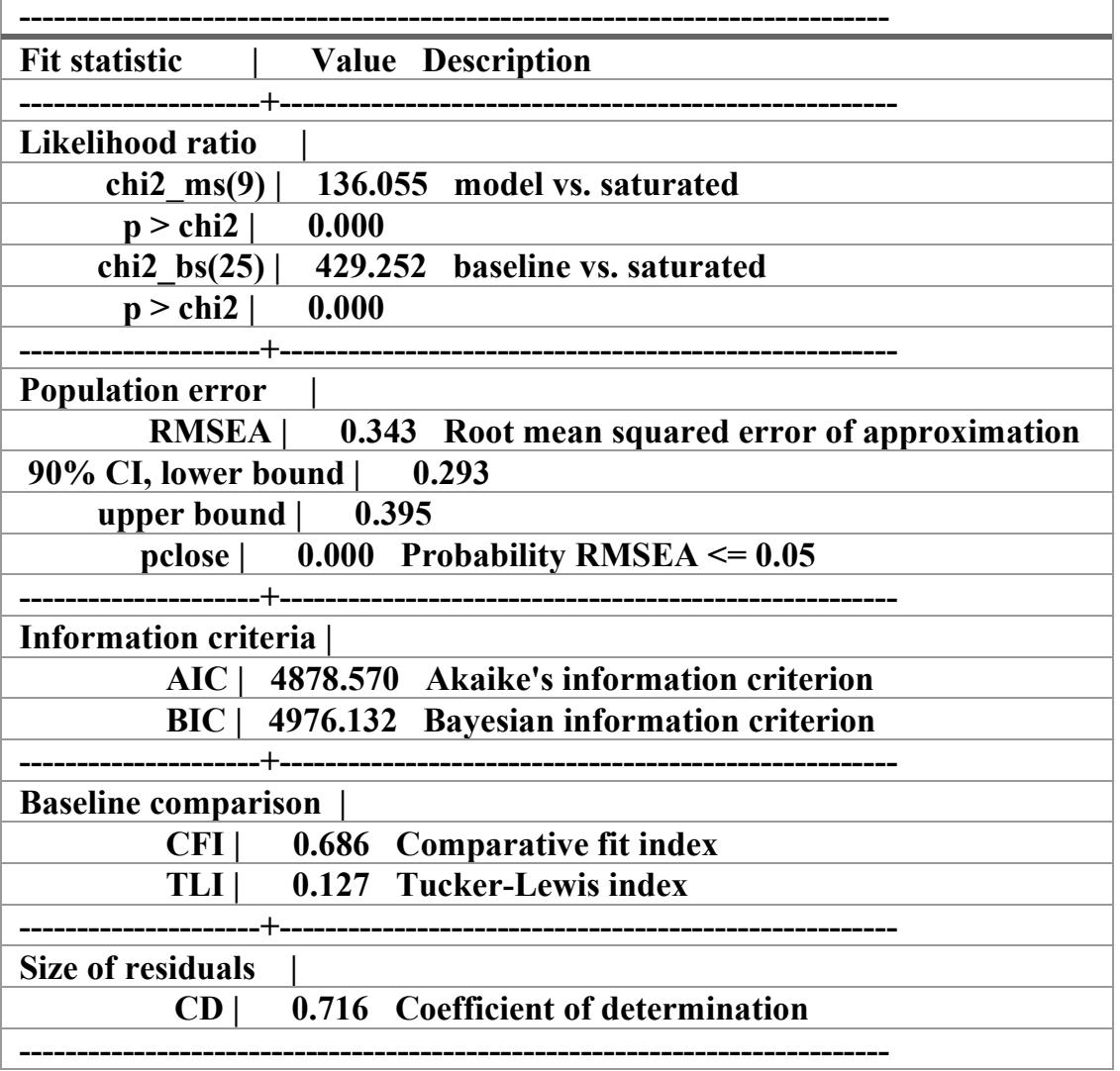

Source: Author's Analysis

A CMINDF ratio $<3.0$, a CFI and TLI close to 0.95 , and a RMSEA $p$ value of $<0.05$, and a SRMR close to 0 indicate good fit (Schreiber, Nora, Stage, Barlow \& King, 2006). As shown in Table 7, all fit statistics satisfy the required thresholds $(\mathrm{CFI}=0.686$; TLI $=0.127$; RMSEA $p<0.05 ; \mathrm{CD}=0.716)$, which means that the model is well fitting the data.

\section{CONCLUSION}

This paper critically examines the socio-economic impact of the COVID-19 pandemic, focusing on four developed nations of the world, including China, Germany, UK and US. Survey data was used to analyze the relationship among eight critical socio-economic variables, including economic stability, daily living, mental health, worry about COVID-19, Satisfaction with the national government's response to the COVID-19, people's personal finances, Satisfaction with fellow citizens' response to the COVID-19, and Satisfaction with hospitals' response to the COVID-19. Considering the complexity of the interrelationship between the variables, a structural equation modelling approach was used to assess the impact of the COVID-19 on these variables.

There is no denying that the COVID-19 pandemic has affected the daily lives of people. This is also having negative effect on their ability to contribute meaningfully to economic activities, which ultimately affects the economic stability of their nations as a whole. The findings from this paper draws the attention of the government as a critical force in resuscitating the economy post COVID-19. The government would have to formulate and implement policies that will inspire confidence as at present, people are somewhat not satisfied with the national government's response to the COVID-19 / coronavirus pandemic, as the level of satisfaction is just average.

The result from this study also shows the importance of the health sector in nation-building. The health sector has critical roles to play beyond taking care of the sick that have contracted the COVID-19. The health sector is 
critical in inspiring confidence in the public and causing citizens to be mentally, psychologically and emotionally stable. Mental stability is needed for citizens to carry out their economic activities and contribute meaningfully to economic stability; therefore, the health sector has important role to play during and after the COVID-19 outbreak. By implication, this is a call to government to strengthen the healthcare sector and health institutions by formulating policies and dedicating more resources to revamp the health sector, as a healthy nation makes a wealthy nation. The need to consolidate the health sector is further established by the result that people seem to be generally well satisfied with hospitals' response to the COVID-19 / coronavirus pandemic.

The road to economic recovery also starts with the actions of citizens in containing the spread of the COVID19 pandemic. In other words, economic recovery following the COVID-19 outbreak is not the sole responsibility of the government or the health sector. People have their parts to play as well by, at the minimum, complying with the safety measures emplaced by the government and authorized healthcare givers. There is need for urgent action in this regard as result shows that people appear not to be satisfied with fellow citizens' response to the COVID19 / coronavirus pandemic Further, the private sector can also complement the efforts of the government in the path towards economic recovery. The need for people to take responsibility for their safety and the safety of others cannot be overemphasized considering that their psychological, mental and physiological wellbeing affect their ability to carry on economic activities and contribute meaningfully to economic stability. By and large, everyone has a part to play on the road to economic recovery post COVID-19, and how well the role is played will largely determine the velocity or speed at which their nation recovers from the socio-economic consequences of the COVID-19 pandemic.

This study contributes to knowledge in that it is the first, to the author's knowledge, to analyze the socioeconomic impact of the COVID-19 outbreak using a structural equation modelling approach. The originality of the paper also stems from the consideration that it integrates data from four major developed countries of the world, thereby extending the generalizability of the result. The current study is however without limitations. The study made use of secondary data obtained from a survey covering four countries-United States, United Kingdom, Germany and China. Considering that the impact of the COVID-19 on social and economic system may be country-specific, the results obtained from this study may not be generalizable to other countries. This however provides the opportunity to conduct country-specific studies on the socio-economic impact of the global pandemic. In addition, the study analyzed survey data spanning a one-month period when the COVID-19 cases peaked all over the world. Since the socio-economic impact of the COVID-19 may be dependent on time, it may be worthwhile to obtain and analyze data at another point in time when the spate of the pandemic is slowing down. On a final note, acknowledging that survey data may suffer common method bias (Speklé \& Widener, 2018), steps were taken to minimize common method variance by using different measurement scale to measure variables.

\section{REFERENCES}

Aboramadan, M., \& Borgonovi, E. (2016). Strategic management practices as a key determinant of superior nongovernmental organisations performance. Problems of management in the 21st century, 11 (2), 71-92.

Abramovitz, M. (2017). Regulating the lives of women: Social welfare policy from colonial times to the present. London: Routledge.

AbuKasim, N. A., \& Minai, B. (2009). Linking CRM strategy, customer performance measures and performance in the hotel industry. International Journal of Economics and Management, 3(2), 297-316.

Avgar, A.C., Givan, R.K. \& Liu, M. (2011). A balancing act: Work-life balance and multiple stakeholder outcomes in hospitals. British journal of industrial relations, 49(4), 717-741. Doi: 10.1111/j.14678543.2010.00839.

Boddy, D. (2012). Essentials of management: A concise introduction. Essex, England: Pearson Education Limited. BPP (2008). CIMA Paper P2: Management accounting: Decision management study text (5 $5^{\text {th }}$ ed.). London: BPP Learning Media Ltd.

Centers of Disease Control and Prevention (2020). Coronavirus Disease 2019 (COVID-19) - Transmission. Centers for Disease Control and Prevention. 17 March 2020. Retrieved 23 May 2020.

Clamp, R. (2020). "Coronavirus and the Black Death: spread of misinformation and xenophobia shows we haven't learned from our past". The Conversation. Retrieved 11 May 2020.

Garrett, C. (2008). The effect of nurse staffing patterns on medical errors and nurse burnout. AORN Journal, 87(6), 1191-1204.

Ghauri, P., \& Grønhaug, K. (2005). Research Methods in Business Studies: A Practical Guide (3 ${ }^{\text {rd }}$ ed.). Harlow: Financial Times Prentice Hall.

Government of the United Kingdom. (2020). "Coronavirus (COVID-19): latest information and advice". Government of the United Kingdom. Retrieved 7 June 2020.

Gray, B. (2009). The emotional labor of nursing: Defining and managing emotions in nursing work. Nurse education today, 29(2),168-175.

Hye, K. K. (2014). Work life balance and employee performance. The mediating role of affective commitment. 
Global Business Management Research: An International Journal, 6(1), 37-51.

Jensirani, M. \& Muthuman, A. (2017). A study on work life balance of nurses in Kovilpatti town. International Journal of Science, Technology and Management, 6(2),114- 131.

Mullins, L.J., \& Christy, G. (2013). Management and organisational behaviour. London: Financial Times Publishing International.

Nikel, D. (2020). "Denmark Closes Border To All International Tourists For One Month". Forbes. Retrieved 1 June 2020.

Phillison, E. (2000). Economic Epidemiology and Infectious Diseases", Handbook of Health Economics, eds. A.J. Culyer, \& J. P. Newhouse, 1B, North Holland Elsevier.

Schreiber, J. B., Nora, A., Stage, F. K., Barlow, E. A., \& King, J. (2006). Reporting structural equation modelling and confirmatory factor analysis results: A review. The Journal of Educational Research, 99(6), 323-338. https://doi.org/10.3200/JOER.99.6.323-338.

Speklé, R. F., \& Widener, S. K. (2018). Challenging issues in survey research: Discussion and suggestions. Journal of Management Accounting Research, 30(2), 3-21.

The New York Times (2020). Coronavirus Live Updates: Europe Prepares for Pandemic as Illness Spreads from Italy. The New York Times. 26 February 2020. Retrieved 20 May 2020.

World Health Organization. (2020). Coronavirus disease 2019. World Health Organization. Retrieved 7 June 2020. World Health Organization. (2020). WHO Director-General's opening remarks at the media briefing on COVID19-11 March 2020. World Health Organization. 11 March 2020. Retrieved 9 June 2020.

Oseni, A., A. (2020). Examining Implementation of Policy Effects on Coronavirus (Covid-19) in United State of America. Journal of Law, Policy and Globalization, 96, 2020.

APPENDIX: DATA SET ON SOCIO-ECONOMIC CONSEQUENCES OF CORONA VIRUS DISEASE 2019 (COVID-19) OUTBREAK IN US, UK, GERMANY AND CHINA

\begin{tabular}{|c|c|c|c|c|c|c|c|}
\hline ECONOMY & LIFE & MENTAL & WORRY & GOVT & FINANCE & CITIZEN & HOSPITAL \\
\hline 60 & 7.4 & 21 & 64 & & 41 & 83 & \\
\hline 61 & 7.4 & 27 & 59 & & 41 & 75 & \\
\hline 64 & 7.2 & 8 & 63 & & 35 & 86 & \\
\hline 59 & 7.4 & 19 & 64 & & 35 & 81 & \\
\hline 67 & 7 & 21 & 42 & & 36 & 73 & \\
\hline 57 & 7.4 & 14 & 64 & & 42 & 76 & \\
\hline 60 & 6.9 & 14 & 60 & & 46 & 73 & \\
\hline 67 & 7 & 16 & 58 & & 32 & 68 & \\
\hline 60 & 6.9 & 21 & 61 & & 42 & 74 & \\
\hline 63 & 7.2 & 16 & 48 & & 38 & 78 & \\
\hline 74 & 7 & 17 & 56 & & 36 & 73 & \\
\hline 71 & 6.7 & 25 & 59 & & 38 & 74 & \\
\hline 72 & 7 & 19 & 53 & & 33 & 80 & \\
\hline 67 & 7 & 17 & 54 & & 33 & 73 & \\
\hline 64 & 7.2 & 21 & 54 & & 38 & 72 & \\
\hline 55 & 6.7 & 17 & 52 & & 31 & 80 & \\
\hline 67 & 7.1 & 19 & 61 & & 39 & 68 & \\
\hline 66 & 6.8 & 22 & 44 & & 34 & 80 & \\
\hline 56 & 6.9 & 23 & 57 & & 42 & 73 & \\
\hline 72 & 7.2 & 29 & 69 & & 48 & 66 & \\
\hline 79 & 6.8 & 16 & 61 & & 38 & 74 & \\
\hline 71 & 6.6 & 17 & 54 & & 32 & 81 & \\
\hline 80 & 6.9 & 18 & 62 & & 30 & 76 & \\
\hline 69 & 6.9 & 27 & 60 & & 39 & 85 & \\
\hline 64 & 6.7 & 27 & 57 & & 32 & 80 & \\
\hline
\end{tabular}




\begin{tabular}{|c|c|c|c|c|c|c|c|}
\hline ECONOMY & LIFE & MENTAL & WORRY & GOVT & FINANCE & CITIZEN & HOSPITAL \\
\hline 63 & 6.9 & 22 & 48 & & 39 & 76 & \\
\hline 71 & 7.1 & 30 & 50 & & 41 & 75 & \\
\hline 62 & 6.8 & 20 & 53 & & 28 & 74 & \\
\hline 64 & 7.1 & 23 & 63 & & 36 & 69 & \\
\hline 56 & 6.6 & 19 & 52 & & 34 & 77 & \\
\hline 62 & 7.2 & 31 & 66 & 59 & 19 & 32 & 72 \\
\hline 59 & 6.3 & 29 & 48 & 54 & 24 & 28 & 79 \\
\hline 72 & 6.5 & 22 & 65 & 60 & 17 & 37 & 78 \\
\hline 58 & 6.6 & 28 & 54 & 58 & 21 & 30 & 79 \\
\hline 66 & 6.9 & 33 & 52 & 55 & 18 & 41 & 85 \\
\hline 66 & 6.3 & 31 & 54 & 57 & 20 & 37 & 78 \\
\hline 60 & 6.5 & 27 & 52 & 59 & 17 & 36 & 71 \\
\hline 65 & 6.1 & 23 & 45 & 53 & 17 & 36 & 74 \\
\hline 61 & 6.9 & 28 & 51 & 54 & 25 & 30 & 72 \\
\hline 64 & 6.9 & 22 & 54 & 53 & 18 & 39 & 72 \\
\hline 67 & 6.9 & 28 & 51 & 59 & 15 & 47 & 78 \\
\hline 67 & 6.5 & 28 & 44 & 57 & 23 & 39 & 84 \\
\hline 52 & 6.3 & 22 & 52 & 62 & 22 & 43 & 75 \\
\hline 68 & 7.2 & 28 & 59 & 57 & 21 & 40 & 79 \\
\hline 60 & 6.2 & 25 & 50 & 54 & 14 & 48 & 75 \\
\hline 57 & 6.5 & 30 & 50 & 58 & 17 & 35 & 75 \\
\hline 65 & 6.7 & 25 & 54 & 62 & 21 & 48 & 80 \\
\hline 63 & 6.3 & 25 & 44 & 57 & 14 & 44 & 80 \\
\hline 49 & 6.2 & 32 & 41 & 55 & 20 & 38 & 72 \\
\hline 65 & 6.4 & 26 & 39 & 52 & 23 & 36 & 64 \\
\hline 56 & 6.2 & 21 & 49 & 54 & 23 & 40 & 75 \\
\hline 56 & 6.1 & 24 & 50 & 49 & 13 & 46 & 75 \\
\hline 57 & 6.4 & 21 & 48 & 59 & 21 & 49 & 71 \\
\hline 58 & 6.3 & 14 & 39 & 63 & 15 & 51 & 71 \\
\hline 71 & 6.3 & 25 & 46 & 57 & 21 & 42 & 77 \\
\hline 55 & 6.7 & 29 & 50 & 60 & 30 & 39 & 81 \\
\hline 61 & 6.1 & 27 & 38 & 65 & 10 & 46 & 79 \\
\hline 64 & 6.3 & 34 & 50 & 59 & 24 & 42 & 78 \\
\hline 51 & 6 & 29 & 37 & 51 & 19 & 41 & 73 \\
\hline 57 & 6.1 & 16 & 43 & 64 & 16 & 37 & 82 \\
\hline 49 & 7.3 & 41 & 69 & 54 & 29 & 20 & 86 \\
\hline 45 & 7.3 & 35 & 68 & 57 & 21 & 12 & 79 \\
\hline 49 & 7.1 & 31 & 57 & 66 & 24 & 20 & 81 \\
\hline 51 & 7.7 & 38 & 66 & 59 & 26 & 30 & 89 \\
\hline 54 & 7.5 & 34 & 52 & 65 & 25 & 38 & 83 \\
\hline 43 & 7.2 & 34 & 60 & 60 & 29 & 27 & 85 \\
\hline 54 & 7.4 & 41 & 59 & 64 & 15 & 35 & 85 \\
\hline 50 & 7.7 & 30 & 63 & 62 & 25 & 36 & 89 \\
\hline
\end{tabular}




\begin{tabular}{|c|c|c|c|c|c|c|c|}
\hline ECONOMY & LIFE & MENTAL & WORRY & GOVT & FINANCE & CITIZEN & HOSPITAL \\
\hline 52 & 7.4 & 27 & 57 & 66 & 24 & 39 & 86 \\
\hline 52 & 7.2 & 32 & 63 & 56 & 24 & 40 & 83 \\
\hline 58 & 7 & 34 & 54 & 56 & 20 & 41 & 84 \\
\hline 49 & 7.2 & 27 & 49 & 47 & 21 & 33 & 79 \\
\hline 55 & 7.3 & 33 & 61 & 57 & 23 & 44 & 90 \\
\hline 48 & 7.3 & 28 & 64 & 43 & 20 & 27 & 88 \\
\hline 53 & 7.2 & 34 & 64 & 59 & 23 & 33 & 84 \\
\hline 61 & 7.4 & 24 & 55 & 61 & 32 & 35 & 86 \\
\hline 55 & 7.2 & 42 & 64 & 59 & 21 & 36 & 89 \\
\hline 60 & 7.3 & 32 & 57 & 65 & 18 & 40 & 88 \\
\hline 52 & 6.9 & 31 & 54 & 62 & 23 & 43 & 87 \\
\hline 54 & 7.4 & 29 & 68 & 60 & 21 & 39 & 80 \\
\hline 53 & 6.9 & 34 & 63 & 60 & 30 & 47 & 90 \\
\hline 41 & 6.5 & 32 & 65 & 58 & 23 & 43 & 87 \\
\hline 44 & 7 & 33 & 59 & 50 & 18 & 46 & 87 \\
\hline 55 & 7.2 & 39 & 62 & 56 & 28 & 48 & 90 \\
\hline 57 & 6.9 & 34 & 57 & 58 & 20 & 38 & 85 \\
\hline 58 & 7.1 & 30 & 56 & 59 & 21 & 42 & 91 \\
\hline 53 & 6.7 & 35 & 58 & 64 & 22 & 49 & 85 \\
\hline 62 & 6.9 & 36 & 53 & 50 & 15 & 50 & 89 \\
\hline 61 & 7.3 & 43 & 62 & 52 & 28 & 52 & 87 \\
\hline 60 & 6.6 & 36 & 50 & 48 & 25 & 44 & 83 \\
\hline 62 & 7.3 & 27 & 65 & 39 & 31 & 33 & 74 \\
\hline 66 & 6.7 & 22 & 54 & 42 & 34 & 37 & 71 \\
\hline 62 & 7 & 33 & 54 & 38 & 41 & 40 & 72 \\
\hline 51 & 7 & 18 & 58 & 39 & 24 & 36 & 82 \\
\hline 61 & 7.4 & 30 & 66 & 35 & 34 & 28 & 73 \\
\hline 69 & 7.1 & 26 & 56 & 41 & 30 & 33 & 74 \\
\hline 72 & 7.3 & 25 & 62 & 44 & 25 & 27 & 81 \\
\hline 60 & 6.8 & 16 & 54 & 42 & 24 & 36 & 72 \\
\hline 60 & 6.6 & 32 & 56 & 38 & 30 & 39 & 80 \\
\hline 67 & 6.9 & 32 & 62 & 45 & 30 & 38 & 80 \\
\hline 61 & 7.2 & 27 & 70 & 42 & 36 & 33 & 76 \\
\hline 66 & 7 & 21 & 59 & 41 & 27 & 38 & 79 \\
\hline 74 & 7.3 & 30 & 64 & 41 & 29 & 34 & 76 \\
\hline 65 & 7.4 & 34 & 67 & 30 & 30 & 34 & 81 \\
\hline 66 & 6.9 & 29 & 63 & 30 & 30 & 34 & 82 \\
\hline 59 & 6.7 & 26 & 54 & 38 & 28 & 30 & 69 \\
\hline 64 & 7.3 & 29 & 63 & 33 & 25 & 35 & 74 \\
\hline 69 & 7 & 29 & 63 & 42 & 23 & 40 & 81 \\
\hline 73 & 7.1 & 23 & 65 & 39 & 29 & 40 & 76 \\
\hline 73 & 7.2 & 31 & 59 & 39 & 28 & 37 & 76 \\
\hline 74 & 7.2 & 26 & 57 & 39 & 27 & 36 & 76 \\
\hline
\end{tabular}




\begin{tabular}{|r|r|r|r|r|r|r|r|}
\hline \multicolumn{1}{|l|}{ ECONOMY } & \multicolumn{1}{|l|}{ LIFE } & \multicolumn{1}{l|}{ MENTAL } & \multicolumn{1}{l|}{ WORRY } & \multicolumn{1}{l|}{ GOVT } & \multicolumn{1}{l|}{ FINANCE } & \multicolumn{1}{l|}{ CITIZEN } & HOSPITAL \\
\hline 69 & 7.2 & 29 & 65 & 38 & 26 & 44 & 76 \\
\hline 69 & 7 & 28 & 57 & 46 & 38 & 45 & 80 \\
\hline 64 & 6.8 & 30 & 59 & 37 & 22 & 45 & 71 \\
\hline 67 & 7.1 & 29 & 61 & 46 & 30 & 41 & 32 \\
\hline 69 & 7.1 & 32 & 64 & 30 & 24 & 28 & 82 \\
\hline 66 & 6.8 & 25 & 56 & 25 & 27 & 35 & 79 \\
\hline 66 & 7.1 & 33 & 67 & 39 & 26 & 42 & 74 \\
\hline 66 & 7.4 & 32 & 62 & 32 & 38 & 25 & 85 \\
\hline 66 & 6.8 & 30 & 60 & 34 & & 74 \\
\hline
\end{tabular}

Source: Curled from statistica (https://statistica.com). 